\title{
Group Relations as Ritual (from seduction to translation)*
}

\author{
Carlos Sapochnik ${ }^{* *}$
}

\begin{abstract}
Group relations conferences in the Tavistock tradition make use of psychoanalytic and systemic perspectives to bring into focus group dynamics around boundaries, roles, task, and authority, assisting the participants to move from fragmentation to integration, while considering possible applications of the learning to the individual's organisational life. In spite of commonalities, no two conferences are ever alike-as epitomised by a familiar statement at opening plenaries that neither participants nor staff know what is going to happen in that particular conference. While this may be axiomatic, it also functions as a strategy of ritual seduction.

Ritual may be understood as a socially approved practice, a pathological enactment, or even a sinister dimension at the level of a cult. The paper considers how ritual behaviour is in evidence in group relations on the Tavistock model and the functions it may serve, including protecting from a both feared and desired exploration of sexuality.

The argument draws from a psychoanalytic understanding of the frame, exploring the nature and need for ritual practices. It considers issues of tradition, leaders as shamanic figures, and the group relations conference as a particular type of performance with the purpose of finding a translation for (and recognition of) socially ambivalent feelings-towards both potential transformation and growth as well as for managing the problematic certitude of the death drive.
\end{abstract}

Key words: group relations, psychoanalysis, ritual, seduction, sexuality, performance, translation.

\section{A DREAM-LIKE INTRODUCTION}

Most of them arrived well before it began, a few did so just in the nick of time, and one or two even after it had started. They had seen the publicity through professional networks and ostensibly wanted to learn from direct experience. The promise was a level playing fieldthere would be no lectures or theories to feel inadequate about, participants would all be the same, equally open to one another. The

*Paper presented at the OPUS International Conference on Organisational and Social Dynamics, London, 21-22 November 2014

**Address for correspondence: E-mail: carlos@sapochnik.com 
prospect of five long days to come together seemed very exciting and also frightening. Some had been warned by well-intentioned acquaintances that these events foster violent and dangerous situations, that people go mad (with anger and desire), relationships are made, broken, and reshaped, but also that it would be an enlightening experience-and that, once over, being with others (at work, in friendships, relationships, family) would never be the same.

A small group had been selected through a secret process by the leader and his close associates to play a particular role as experienced performers. They had arrived a day earlier to introduce themselves to each other, expose their vulnerabilities, and tell of their dreams and apprehensions. They had carefully planned their deployment, ending their long discussions with a communal dinner that made them feel readier to come into contact with the participants the following day. They had agreed to dress in a considered style of restrained celebration-most (but not all) of the men in formal attire, while the women would wear elegant outfits and some casual garments but no jeans. The women would appear more different from each other than the men did, even if one man might wear an extraordinarily colourful or amazingly crumpled shirt.

It was now close to the starting time, and the participants had been directed on arrival to gather in the largest room, where they were surprised to find almost a hundred chairs in row after row in straight lines, facing another row of chairs at the front. They began to take their places, mostly in the middle and back of the room, though some sat singly and daringly on their own, confronting the eerily empty row facing all the others. Some had a vacant expression, some appeared to read the boring handbooks they had been given, and others watched with apparent interest the entrance of those who might be known from different contexts.

And now the performers started coming in, in ones or twos. They seemed to know their allocated seat in the row facing all the others, and took their place without hesitation. A grave-looking person for whom a seat had been left unoccupied in the centre came in just before the very last performer, who walked in exactly as the wall clock showed the starting time, closed the door, and took the last seat in that front row.

The room seemed now complete (even if a few chairs were still empty). The person in the centre of the front row stood up, introduced himself as the director, welcomed the participants, invited those seated at either side of him to introduce themselves as staff, and proceeded to read from a script explaining-in terms that did not make immediate sense- the intention and the process of what would follow 
each day, asking those in the facing row who seemed in charge of a particular aspect of the whole event, to say a few words about their respective areas of responsibility.

They did so, standing up to speak. This appeared orchestrated since they all seemed to do it in the same way, waiting to be called, with a similar deference to authority. At some point, the one who had come in last spoke about administrative and practical arrangements. Beyond the security announcements there seemed to be quite a few instructions-what should happen if one wanted to communicate something to the staff, the way to communicate to the rest of the participants, and a quaint preoccupation with time in respect of absences, lateness, and the precise location of a "master clock" from which all the many activities would be accurately timed through the five days.

Most of what the director said, in a not unfriendly but distant manner, was misheard, not understood, too complex or too obvious and simple, empty of meaning or unbearably full. It felt as if it had all been said before, with a conviction of its truth. At one point the director indicated that "although staff have attended many events such as this one in the past, whatever will happen in this particular one is still unknown as none of us here has been to this event before".

The participants looked at each other and at those in the front. This was not what they had anticipated. And suddenly the director said that the brief introduction had now ended-and for the remainder of the exactly one-hour-long session participants would have the opportunity to discuss their present experience of "crossing the boundary" into the event and, before finally sitting down, asked: "How would you like to begin?"

Confusion and fear gripped the room. The staff at the front were motionless, looking at the participants, who looked back at them and each other. Some participants fumbled with their handbooks. A participant spoke after a few seconds to confide that the silence was too unpleasant, because of not knowing anyone. Another ventured that such a formal introduction was unnerving, followed by someone who blamed the chair arrangement, which seemed unnecessarily authoritarian, creating awe of the row of staff at the front, who remained silent. Some participants introduced themselves, some stood up to speak, some remained seated, some proposed that, to manage this unmanageable or poorly managed arrangement each person should give in turn their name and background, some that the chair arrangement should be altered, some berated the director for their discomfort and creating such a violently artificial situation.

Although some participants tried to offer thoughtful reflections on their experience they could not be heard because the mood in the room 
had changed from expectation to frustration, to anger, and there was a palpable wish for action to relieve the group from what was experienced as an unbearable tension. A participant asked the membership why were they allowing themselves to be intimidated. A number of responses followed fast, one upon the other, and just as this exasperated participant began to berate the others for their passivity and started to lead by example, standing up to initiate a change to the chair arrangement, one of the staff, speaking slowly but audibly, pointed out that the situation was being experienced as too uncomfortableit seemed that the group shared the belief that (any) action would relieve it from the intolerable feelings arising from the invitation by the director to think about the transition. There was no pause. Participants could not hear this intervention about what might be happening to this group almost gripped by panic, neglected and frightened by a careless team of staff. Since their interventions did not offer a solution, those in charge were confirming their inability to manage the level of emotion in the group. Strong feelings, which had been in the making from long before the participants entered the room, had now found a crack to fizzle through.

Whether the participants agreed to explore by exchanging thoughts and feelings and remained seated in the orthogonal grid layout they had first encountered, or acted on their perceived need to reconfigure the room, they realised that taking action calmed some anxieties but not others. Staff made brief interventions with uneven results. After a while the mood settled, some conversation began to seem possible, to which staff contributed sparingly, always spacing their interventions, never following immediately after each other.

Suddenly, while one of the participants was talking and in mid-sentence, the director stood up without a word - and all the staff, as if on cue, stood up at once and followed him out of the room, to the general (voiced and silent) stupefaction of the participants.

\section{LEARNING $<>$ EXPERIENCE}

The previous section will have local variations but describes a rather typical Opening Plenary in a Tavistock-style group relations conference. These events are presented as learning environments in the "Tavistock tradition" (there are no lectures or seminars) usually lasting from three to six days (although there are longer versions of up to two weeks), with the purpose of exploring a range of well defined systemic concepts such as task, role, boundaries, leadership, followership, authority, and organisation. While such events usually have a powerful impact on the individual, their emphasis is on attending to 
unconscious and systemic processes in group dynamics rather than to individual plight, as the approach "concentrates on the individual only in so far as s/he is manifesting something on behalf of the whole group" (Hayden \& Molenkamp, 2002, p. 4).

The overall task is to experience and examine conscious and unconscious processes of group dynamics as they happen. Conferences are structured as a number of linked events, arranged in a scaffolding process of increasing complexity to facilitate the participants' learning from their experience of group interactions in the here-and-now. A number of review events in small and large groups assist participants to take stock and make sense of their learning and on the last day, participants consider and reflect on a critical incident at work that is discussed in small groups in the light of the reframing derived from experiences sustained during the conference.

The main conceptual tools in the Tavistock model are described as "systems psychodynamics", although the psychoanalytic vertex has become contested and the practice currently oscillates uneasily between learning and training (Lousada, 2015). Participants come from a wide variety of backgrounds, some of them already familiar with the notion of the dynamic unconscious through psychoanalytic psychotherapy or courses of study and, by and large, they are surprised by what they encounter as

the model deliberately strip[s] away the structures provided by everyday work-roles. They thus leave as the primary task of groups to reflect on the states of mind which emerge in their absence. (Rustin, 2003, p. 200)

Participants usually (but not always) derive a valuable experience, depending on their own contributions, conference leadership and staff, and the wider organisational and social context. The key strategy is described as "learning from experience", which has an active and a passive element, "peculiarly combined" (Dewey, 1916, p. 139). To have an experience requires both trying (an active component) - the meaning of which is explicit in the connected term experiment-but also the passive experience of undergoing. When we experience something we act upon it, we do something with it; and we then suffer or undergo the consequences-we do something to the thing, which then does something to us in return. The connection of these two phases of experience measures the fruitfulness or value of the experience.

Attending a conference has an immediate impact as well as a slow release quality, as the individual returns to the work environment with hard-won insights about group functioning and her/his contribution, to be developed through further practice. Although an astonishing and very artificial environment (with apparently no task within 
extraordinarily tight boundaries) group relations conferences replicate and reframe some areas of experience, offering potential meta learning strategies to understand and manage in a world of social relations outside the conference confine. Yet change can be both desired and anticipated as catastrophic. Bion proposed that adults have a hatred of learning because learning

means thinking about one's own painful emotional experience of helplessness, dependency, and frustration. ... Experience cannot be known in advance. While undergone, there is a kernel of unthinkability that incurs mental pain. (Britzman, 2009, p. 39)

Even if learners engage willingly they cannot do so without contradictions-learning from experience does not proceed in a linear way. In order to make sense of a new situation, this has to be placed alongside a previous similarly dislocating emotional experience. In "A note on the "mystic writing-pad' " (1925a), Freud was

concerned with explaining how the open perceptual present and the registered mnemonic past cooperate in experience. Consciousness is enigmatically involved with both, taking account as it does of past experience in the present situation. (Eng, 1980, p. 136)

Undergoing or being affected by an experience elicits different defences as catalysts that make it possible to process (digest) it. Hence the importance of these conferences as group events, because the actual presence of others makes it possible to see the dynamics at work. Learning is both an individual and a social process, because an Other is always present in phantasy, since

the individual is and always has been, a member of a group, even if his membership of it consists of behaving in such a way that reality is given to an idea that he does not belong to a group at all. (Bion, 1961, p. 168-169)

However, group relations conferences do offer an outcome, which does not stem from the actual sequence that is undergone, but from the arduous experience of undergoing it, "as if learning has always to take place at the edge of exasperation" (Gosling, 1981, p. 161). Hence another characteristic of these events, common to participants and staff, is the heroic effort in surviving them, eliciting a (perverse) satisfaction in enduring the experience of suffering the group, crossing an imaginary boundary into madness. In effect,

the experience of being placed in groups which have no specific work to do, other than to reflect on their own states of mind and feeling, is a procedure designed to generate uncertainty and anxiety. (Rustin, 2003, p. 192) 
While group relations developed in the mid twentieth century, they are not a new phenomenon as they inherit the human tradition of making use of ceremonial behaviour to induce regression and produce a cathartic experience, which could be mistaken for enlightenment or insight.

What kind of anxieties are unconsciously seeking expression, in the somewhat familiar (rather than known) ways for those who return each day to undergo the experience in an often shocking confrontation with the primitive life of a group and its individuals? Beyond practical justifications such as enhancing professional standing or networking, why do staff, for one, enjoy taking part and compete for the few poorly-paid spaces available in a saturated market? This is not a false opposition. Surely staff and participants attend the event with the intention to grow and assist their organisations to do likewise, by applying a model that facilitates a more efficient organisational life.

Yet, in spite of commonalities, no two conferences are ever alikeas epitomised by the director's familiar statement at an opening plenary that neither participants nor staff know what is going to happen. While this is a frightening truism, its enunciation is performative, that is, it both states a fact, and functions as a strategy of ritual seduction.

\section{RITUAL PRACTICE}

Armstrong has pointed out that we do not often ask ourselves

what fantasies or fears does [the work-group function] arouse in us and how do these fantasies and fears inform the patterning of basic assumption (or basic realm) phenomena, moment by moment? (Armstrong, 2005, p. 149)

How are these fears managed, in both the sense of "processed" and "avoided"? The quote above usefully points out the interrelationship of work group and basic assumption (ba) phenomena (Bion, 1961). Rather than aspiring (as all binaries propose) to privilege one (the good) term and eradicate the (bad) other term, the question becomes: how can the resulting patterns of conjunction find expression towards meaningmaking and learning?

Let us return to the almost oneiric experience narrated in the first section of this paper which, it will be argued, was structured as a ritual and a performance. This is partly explicit and partly covert. In effect, there were a set of experienced performers with different roles acting through a carefully planned choreography (space layout; sequence of entrances; length, context, and mode of intervention; manner of departure), and unprepared performers who at first got caught unawares then joined in and extended the ritual that had been 
proposed. There seemed to be a truth that could not be named and had to be delayed, behaviours that appeared unacceptable from the perspective of conventional conduct (questions might be left unanswered or even ignored, staff spoke in riddles failing to see the gravity of the situation, or were concerned with loftier truths than those accessible to the participants). Some of the participants sided with the selfappointed priests and, like them, spoke in a formal way. Form seemed to take over from content, and the pacing, intonation, and intensity of the staff interventions seemed to hold participants in expectation. All of those present aspired to a learning, intelligence, or revelation to take form. Some were initiates, and some uninitiated (but aspiring to initiation). All were aware that, from one perspective, the proceedings were not usual behaviour but a pretence, like a performance. Yet from another vertex many of the feelings aroused were genuine, and the behaviour that ensued emerged as a surprise. It may be argued that the situation was not dangerous since there were no physical or apparent psychic constraints-participants could leave should they wish (or could do so throughout the week, or might arrive late, or miss some of the sessions), but the level of emotion that the situation engendered was disproportionate to the description of what was going on, the so-called "reality of the situation".

There was a great deal of excitement in all present, though kept under wraps as these were only the first moments of a conference. At this stage the group seemed very far from sharing a sense of purpose, of cooperation in giving a direction to the events. Yet they were contributing, even if not in very explicit ways, cooperating unconsciously in ways that were as yet to be discovered. The initial general feeling was of expectation-something was about to happen. The dramatic impact of the opening was partly felt because there was a cryptic invitation and rejection, as if the participants' responses fell short of the mark, or were banal in respect of a transcendental truth that was being hinted at, and that, infuriatingly, eluded being grasped. Some people (in particular all of those at the front) behaved as if they were acting a part. Was it a celebration, was it a wake? Was it indeed a ceremony of some kind, a ritual performance?

From a psychiatric perspective, ritualised behaviour can be described as repetitive behaviour used by a person or group to prevent or manage anxiety, a typical symptom in obsessive-compulsive disorders (OCD). Most actions undertaken by an OCD subject are unnecessary or even irrelevant as they are not focused on a task-they are therefore considered non-functional. Zor and colleagues (2009) have argued that OCD behaviour consists of short chains of functional acts bounded by long chains (up to $60 \%$ ) of non-functional acts, typifying 
OCD rituals as pessimal (as opposed to optimal) behaviour. This will seem to be in evidence in the sessions to follow, where the formality of behaviour will continue as a repetition, driving participants to exasperation. But ritual may be both a dysfunction and a strategy for engagement.

The concept of ritual attracts a variety of responses. It may be experienced as descriptive, or disguised within a socially approved practice (e.g., the Changing of the Guard), or as a sinister dimension, such as satanic rites. Some authors have denounced what they consider the ritual aspect of group relations, arguing that ritualisation covers up basic assumption phenomena, drawing participants away from exploring other topics in the here-and-now (van Reekum \& Gottlieb, 2009, p. 221). This seems a surprising misreading of the work of Bion, grappling with (and falling for) the messianic phantasy of genuine and definitive liberation, abolishing one of the terms in the binary opposition $b a / \mathrm{W}$, aspiring to a totalising solution. Ritual is considered anti-task while it is in fact an empty signifier, ready to be loaded with contradictory meanings. In effect, while group relations may have a strong ritual component, so do food, sex, work, art, death, sport, and war.

There is a difference between dynamics that need to be ritualised for distress to be avoided; and those that need to be ritualised to engage with difficult emotions and assist the potential of the experience, where ritual plays a containing function. Both are, of course, nonexclusive, and either or both may be in evidence at different stages of the process. But there is a potential for confusing one with the other. The question must then shift from whether group relations is a ritualised practice (a totalising and therefore unsatisfactory assumption), to what might be the function of ritual in assisting the process of this particular experiential learning environment. To what extent is it an intrinsic component of the practice; what functions it may serve towards attaining the generic and specific objectives of the conference; and how does it contribute to the construction of a particular subjectivity in organisational players?

Melanie Klein (1946) proposed her theory of object relations where the good is no less a phantasy than the bad breast. Similarly, the basic assumption group is a form of collaboration, no less a phantasy than the work group. Like the two hypothetical breasts, one does not exist without the other.

We have become so accustomed over the years to reading Bion's subsequent account of group mentality in negative terms, with its emphasis on the regressive elements in group behaviour, as to miss the radicalism of this first venture into the field, that is, the way it was directed to draw out the group's capacity for recovering a sense of internal agency. (Armstrong, 2012, p. 109) 
Bion stated that "the group and the individuals in it are hopelessly committed to a developmental procedure, no matter what might have been the case with our remote ancestors" (1961, pp. 88-89). It is this hopelessness (as an expression of lack) that may be behind ritual as a possible useful strategy for working through the dichotomy $b a /$ Work group functioning. However, from the perspective of the Enlightenment and its aspiration to truth and rationality, ritual has been equated with thoughtlessness. Miller, for one, argued that the model of group relations "is in constant danger of becoming a movement. A movement is fed by and feeds ritual. There are quite subtle pressures on staff to become priests of the ritual" (1990, p. 197). However, rather than proscribing it, it is also possible to usefully interrogate its purpose, as done by Triest and Nutkevitch (2009, p. 64) regarding the long tradition of staff carrying the participants' luggage to their rooms at the Leicester Conference.

Catherine Bell proposed that the fundamental efficacy of ritual activities lies in their ability to have people embody assumptions about their place in a larger order of things, and defined ritualisation as a way of acting designed

to distinguish and privilege what is being done in comparison to other, usually more quotidian, activities ... creating and privileging a qualitative distinction between the "sacred" and the "profane", and for ascribing such distinctions to realities thought to transcend the powers of human actors. (Bell, 1992, p. 74)

Bell identified a number of characteristics in ritual behaviour such as formalism, traditionalism, disciplined invariance (hence the conference consuming preoccupation with exact time), rule governance, sacral symbolism, and performance. Through the stages of the conference a "seasonal pattern" may be perceived, the function of which is to revitalise the old order. It goes through a process of "emptying" rites of mortification and purgation and "filling" rites of invigoration and jubilation -in other words, rites of death and resurrection (Gaster, 1966 quoted in Bell, 1997, p. 7). Emptiness is necessary for something to be created, and although the experience of emptiness may be a source of great anxiety, it is also the precondition for the emergence of something new. Van Gennep (1960) held that all rituals are rites of passage since they serve a transformative function and noted that rituals comprise three phases: (1) separation from the everyday world; (2) transition; and (3) incorporation or return to the everyday world transformed. But a regeneration involves ritual repetition and a sacrifice, namely the actual wish and fear of surrendering individuality to the phantasy of the omnipotent group — the nucleus of the group relations 
insight that Bion named as the trope of groupishness. However, this sequence may not always be completed by participants or staff, and in those cases no transformation is experienced.

What the opening plenary initiates is a sequence of crises, to be amplified and diffused (rather than resolved) through the following days. A crisis is the turning point in an illness when the patient may either die or recover. It entails a peculiar intensity and a form of euphoria. The crises that ensue are geared towards the production of survival, endurance, and enjoyment, as crises of death and resurrection are manifestations of the imperatives of the death drive. They are accompanied by excitement and virtuous feelings (such as when fasting) where adherence to a form or method takes over as a pleasurable experience.

From a psychoanalytic perspective ritual may be considered an obsessive mechanism to appease repressed desires and thus manage psychic conflict. Rituals might, to the degree that they aid the ego's attempt to suppress disruptive or dangerous id impulses, further the cause of adaptation or healthy maturation (Bell, 1997, p. 15). But attention can be paid to the larger structure of the ceremonial as the means to observe the phantasies that the rites embody. The usefulness of the ritual may lay in recognising it as such and an engagement with it, beyond an evacuating catharsis. Ritualised performance is a component of the process of attaining a group relations conference's generic and specific objectives, such as the translation of emotions into representations of reality, making bearable the excitement of a potential exploration (both feared and desired) of sexuality and the death drive. These symbolic practices "are tangible formulations of notions, abstractions from experience fixed in perceptible forms, concrete embodiment of ideas attitudes, judgements, longings, or beliefs" (Geertz, 1973, p. 91). Such emotionally charged performances as are found in a group relations conference serve to model relationships to render them apprehensible as a version of reality.

Unlike genes, and other non symbolic information sources, which are only models for, not models of, culture patterns have an intrinsic double aspect: they give meaning, that is, objective conceptual form, to social and psychological reality both by shaping themselves to it and by shaping it to themselves. (Geertz, 1973, p. 93)

And here is another conundrum, as ritual is not to be taken solely as a model for, but also a model of life within groups and organisations. While achieving a sense of revelation the ritual stabilises a sense of direction. 
In a ritual, the world as lived and the world as imagined, fused under the agency of a single set of symbolic forms, turn out to be the same world, producing thus that idiosyncratic transformation in one's sense of reality. (Geertz, 1973, p. 112)

Referencing Durkheim, Bell proposed that "rituals are designed to arouse a passionate intensity, feelings of 'effervescence', in which individuals experience something larger than themselves" (Bell, 1997, p. 24). Having ritually engaged with the framework of meaning that religious conceptions define, in returning to the common-sense world at the end of the ritual the person is changed. Yet emotions can rise high and the group project difficult feelings into participants or staff. Girard (1979) has proposed that ritual, religion, society, and culture emerge from a foundation in a primal violence, describing a process "in which desire, channelled through the ritual of an original murder, is ultimately enshrined in every social institution, including language" (Bell, 1997, p. 16). In order to repress consciousness of both violence and desire, a human victim is seized as a scapegoat and ritually sacrificed. The ritual sacrifice is the means by which the community deflects or transfers its own madness and violence on to an other who has been made into an outsider. These are the "casualties" fantasised or realised by the group, a grave concern of every group relations conference, assessed by staff at regular points of the conference when they gather to review their members' state of mind and that of the staff and their collective ability to manage sadistic impulses from running riot in the event. According to Bell, Hubert and Mauss pointed to the presence of

two basic processes inherent in all forms of sacrifice, sacralization and desacralization. An essentially profane offering is made sacred-consecrated, in effect-in order to act as a means of communication and communion between the sacred and the profane worlds. At the conclusion of the rite, however, a process of desacralization re-establishes the necessary distinctions between these two worlds that make up day-to-day reality. (Bell, 1997, p. 26)

This process is in evidence in the review and applications groups, designed to integrate the experiences of the membership (and staff, now performing in facilitator rather than consultant role) after the madness of fragmentation sustained during the different events and, in particular, at the healing closing stages by linking the extraordinary conference experiences with ordinary working-life issues. Rituals can then be considered as representing and making contact with the unrepresentable (Botella \& Botella, 2013) to assist potential digestion. 
The central problem of ritual is "that of expressing what cannot be thought of" (Turner, 1962, p. 87), which must emotionally draw the staff into the madness of the conference. However, in writing on the analytic encounter, Kohon has commented on acting out, as a potential source of communication, where

the analyst is kept (is able to keep himself) as a (relatively conscious) observing participant object, [while] in enactment the analyst becomes an (always unconscious) active participant object. (Kohon, 1999, p. 74, italics in the original)

Staff do (or should) understand that they are engaging in an enactment, and

dramatic acting out of a problem may be one way of resolving it. ... and that this dramatic assertion may be in some measure an end in itself ... in so far as ritual is a dramatic expression it is, in some measure, its own reward. (Beattie, 1966, pp. 68-70)

In this process, the staff (as a representation of the group) take up a shamanic function. Shamans are intermediaries or messengers between the human and the spirit worlds with the purpose of alleviating ailments, mending the soul to restore balance and wholeness (Halifax, 1982), crossing over to the underworld to bring back guidance. The shaman takes the ailment on her/himself, becoming sick to understand sickness. Staff take that role in assisting participants to remain in a difficult terrain, experiencing it and questioning it at the same time, acknowledging that the situation is, in some respect, artificial. However, as it happens in the theatre or cinema, the emotions we experience there are not make believe, even if we know we surrender to the manipulation of an artificial environment, which functions both as a protection from getting too close to the core of the experience, and as a mediating device. Consequently the task is to

attend to every piece of the jigsaw puzzle of how to interpret their symbolic acts contributes to understanding the great moments when sickness is brought under priestly control ... [making explicit] the relation of the symbolic to the social order, showing how each gives form to the other in a dynamic intermingling of meanings. (Douglas, 1970, pp. 302-303)

But, is it possible to bring together Dionysian excess with Apollonian rationality?

Turner [1969] argues that anti-structural processes are necessary both for cultural maintenance and cultural change. In post-industrial societies, 
where sacred ritual is no longer regarded as mandatory, the restorative and transformative functions of ritual have been taken over by "entertainment" and other recreational activities which are themselves non obligatory and essentially playful. He terms these anti-structural leisure activities liminoid to distinguish their purely "ludic" character from the "ludic-ergic" character of ritual liminality. (Apter, 2008, p. 196)

Group relations, like other ritual practices such as festivals, produce a primitive state where play and creativity are encouraged while the constraints of social norms become both potentiated and inoperative.

What rituals seem to do ... is to induce the states needed for the ritual, and to do this in such a way that everyone taking part gets to be in the same state together. Indeed this would seem to be the function of all kinds of group performance, such as singing, dancing or playing with others, or going to the theatre, and so on. (Whitehead, 2001, quoted by Apter, 2008, p. 198)

Neither hosts nor guests are innocent (etym.: blameless) and what the conference sets up (for both staff and participants) is a provocation that activates the anxieties that participants and staff have enrolled to feel exposed to, make sense of, and attempt to resolve by overcoming them through ritual, in phantasy and actuality.

\section{SEDUCTION > TRANSLATION}

The concept of provocation implies violence, which need not be malevolent and can be an incitement to think. However, because this provocation revolves around sexuality, it is experienced as problematic to engage with. What becomes contested is our conception of the unconscious that, in Freud's view, was rooted in sexuality and destructiveness, bearing in mind that there was also something intrinsically lacking in sexuality to allow complete discharge and satisfaction (Freud, 1941f[1938], p. 300).

Because group relations conferences were originally based on the object relations theories of Klein and her followers (notably Bion), staff interventions concerning the manifestations of sexuality may centre on object relationships as if these are of a deeper nature-while the emergence of sexuality is considered a defence by the group.

Kleinian thinking called attention to object dependency from the beginning of life, gave precedence to the opposites of the good and the bad object, and raised the breast to a supreme position. This becomes a resistance ignoring

the genital aims with all their conflicting connotations: the difference of the sexes and the difference of generations, the tolerance to otherness, the 
conflict between desire and identification to the object, the acceptance of the loss of control in sexual enjoyment etc. It seems easier to direct oneself towards what is generally taken as granted in terms of disturbances having nothing to do with sexuality. These fixations are seen as reproduction of early mother-baby relationships, usually totally sexless. (Green, 1995, p. 874)

However, "the role of a sexual relationship is not to feed and nurture but to reach ecstasy in mutual enjoyment" (Green, 1995, p. 877), and foregoing acknowledgement of sexuality as an instinctual drive may lead to a loss of vitality in the conference. As Mitchell (2012, p. 48) has pointed out concerning artistic practice, "the looked-down acting out is contrasted with the hailed working through but this misses the creative potential of the enactment". The potential for catharsis (from Greek katharsis "purging, cleansing") as a drawback of ritual, plus the fact that group relations is not psychotherapy-even if it may have therapeutic effects-create a tension that must remain alive rather than become censored. While the purpose of group relations may be both to give expression to and assist participants to overcome primitive anxieties in their group and organisational lives, enabling them to function with normative behaviour without turning a blind eye (Steiner, 1985), the phantasy of instinctual pleasure must not be sanitised.

Paraphrasing Green in respect of psychoanalytic treatment, the hope is that, at the end of the conference the participant (in respect of her/his engagement with organisational situations)

will be able to enjoy life a little more than he used to do before coming into [it] or, as Winnicott says, that he will be more alive, even if his symptoms do not all disappear. (Green, 1995, p. 880)

Hence, membership and staff must connect with their jouissance, in the impossible satisfaction of their desire by a (phantasised) orgiastic erosion of boundaries, yet both enjoying and fearing the enactment of losing their mind to the group. Within the boundarylessness of this highly boundaried environment participants and staff become very excited. But whence this excitement and ensuing repression-and what part do group relations staff play in it?

Jean Laplanche's theory of primal seduction (Laplanche, 1970, 1999) proposed that Freud's abandonment of his seduction theory resulted in the loss of a particular model of trauma and its temporal functioning. Freud termed this concept Nachträglichkeit (translated as aprèscoup in French and by Strachey as deferred action), which Laplanche (1999) translated as afterwardsness. This refers to a "primary traumatic 
inscription" that is excessive and hence remains unassimilated, to be reactivated at a later moment. Its enigmatic sexual meaning is then "precipitated out" and becomes subject to reinscription and/or repression. "The primal situation is one in which a newborn child, an infant in the etymological sense of the word (in-fans: speechless), is confronted with the adult world." (Laplanche, 1989[1987], pp. 89-90, cited by Fletcher, 2007, p. 1249). In his Three Essays on the Theory of Sexuality, Freud had pointed out that a child's relationship with anyone responsible for the child's care provides an unending source of sexual excitation, especially so since the carer, usually the mother, herself regards the child with feelings derived from her own sexuality, treating the child lovingly as a substitute for a sexual object. Yet

(a) mother would probably be horrified if she were made aware that all her marks of affection were rousing her child's sexual instinct and preparing for its later intensity. She regards what she does as asexual, "pure" love since, after all, she carefully avoids applying more excitations to the child's genitals than are unavoidable in nursery care. As we know, however, the sexual instinct is not only aroused by direct excitation of the genital zone. What we call affection will unfailingly show its effects one day on the genital zones as well. (Freud, 1905d, p. 223)

Laplanche argued that what was missing in Freud's account was both the category of the message from the adult, and the model of translation of that message by the infant, and that there is a profound asymmetry in the adult-infant communication.

For the adult has an unconscious and a developed sexuality, and the messages of comfort, reassurance, and love communicated to the infant are, in the strictly psychoanalytic sense, compromise formations-i.e., carriers of inhibited and unconscious sexual excitations and fantasies on the part of the adult. Hence they are enigmatic messages, not just because the infant lacks at this stage an unconscious and the codes to translate them, but crucially because the adult also is unconscious of their significance. (Fletcher, 2007, p. 1252)

Laplanche (2002) proposed that the language of the adult is enigmatic, neither due to strangeness or polysemy but because of its "onesided excess" that introduces a "disequilibrium into the interior of the message" in front of the infant's need to translate it, "both opening up to and defending against the seductive ministrations of the adult" (Fletcher, 2007, p. 1258).

In keeping with his theory of the primacy of the other, Laplanche posits that the presence of the analyst "provokes transference" that is to say, neither "causes" nor "suggests" it, and this "provocation is 
unintentional and takes place when the original adult-infant asymmetry happen to coalesce", and the enigmatic share in the other's message becomes operative (Scarfone, 2013, p. 557). According to Laplanche, the analyst offers the analysand a space, a "hollow" in which the latter may place either something "filled-in" or another hollow.

Laplanche thus distinguishes two modalities of transference. Filled-in transference consists in "the positive reproduction of forms of behaviour, relationships and childhood imagos" (Laplanche, 1989[1987]: 161 [1987: 157]); this is transference as commonly described, i.e. as the repetition of archaic situations. In hollowed-out transference: "We again have a reproduction, but this time it is the childhood relationship that is repeated; it regains its enigmatic character" (ibid.). Laplanche promptly specifies that the two modalities of transference inevitably coexist but if there were nothing but filled-in transference- that is, mere repetition - there would be no resolution in sight. Hollowed-out transference, conversely, implies that "the enigmatic messages of childhood are reactivated, investigated and worked through thanks to the situation itself as it facilitates the return of the enigmatic and secondary revision" (ibid.). (Scarfone, 2013, p. 558)

The seduction by staff is not malicious but inevitable, concerning the excitement of mutual seduction and collective jouissance, in the phantasy of orgiastic excess and sacrifice. How can this complexity of excitement be engaged with towards growth-without censoring the representations (in acting out or enactments) of instinctual discharge? As Michael Balint used to put it: "no seduction-no production" (Kohon, 2014). There is a difficulty in continuing to use psychoanalysis as an investigative tool because something coming into consciousness from repression is always painful and difficult to bear and, moreover, this process is always incomplete, since "for every process of translation there is a remainder, something resistant to metabolization that remains à traduire, yet to be translated" (Fletcher, 2007, p. 1256).

José Bleger, in his lucid paper "Psycho-analysis of the psychoanalytic frame" (1967), offered a formulation of possible application to group relations, positing that the analytic situation

comprises phenomena which constitute a process that is studied, analysed, and interpreted; but it also includes a frame, that is to say, a "non-process", in the sense that it is made up of constants within whose bounds the process takes place. (Bleger, 1967, p. 511)

The frame, similar to the one proposed by the analyst in the analytic treatment, refers to a strategy (such as Miller's 3 Ts of territory, task, and time) rather than to a technique, to be considered a meta-behaviour, 
within which phenomena can be distinguished as behaviour, but in reference to the frame, such as late arrival, etc. Bleger considered the frame the most primitive part of the personality, as the fusion egobody-world "on whose immobility depend the formation, existence, and differentiation (of the ego, the object, the body image, the body, the mind, etc.)" (Bleger, 1967, p. 514). Although Jaques (1955) considered that social institutions are (unconsciously) used as a defence against psychotic anxiety, Bleger believed them to be "the depository of the psychotic part of the personality, i.e. the undifferentiated and non-dissolved portion of the primitive symbiotic links" (Bleger, 1967, p. 514).

Hence, if the frame is not systematically analysed, it may become stabilised like an addiction as the foundation of the organisation of the personality, and the patient's ego is "adjusted and modelled upon the institutions of which he is part" (Bleger, 1967, p. 516). The therapeutic alliance is an alliance with the healthiest part of the patient, and this is true of the process but not of the frame. In the latter, the alliance is established with the psychotic (or symbiotic) part of the patient's personality.

The analyst should accept the frame the patient brings (which is his "meta-ego") because there the non-solved primitive symbiosis is found summed up. But we must state, at the same time, that to accept the patient's "meta-ego" (the frame) does not mean to abandon one's own, by means of which one is able to analyse the process and to transform the frame itself into a process (Bleger, 1967, p. 517).

Something similar happens in group relations conferences, where the frame (as the conference ritual) must be maintained to study the relationship of the members to the frame, within which there may be a range of modes of engagement, from collusion and passive acceptance, competition, subversion and a refusal to play by "the rules of the game", to creative transformation. This is an exercise in translation whereby participants struggle to represent unconscious experience into affect and language.

\section{AN UNCERTAIN CONCLUSION}

This paper has argued the importance of the ritual dimension of group relations as a strategy for understanding the shameful pleasure of destructive and sexual impulses if learning about individuals and groups is to proceed. The last two sections-drawing on the writings of André Green, Jean Laplanche, and José Bleger-asserted that this can be done within a sustained psychoanalytic framework that fosters the potential for creative participation and considerable aesthetic 
pleasure that the experience can afford. But, how do we tell the difference between a genuine learning experience from a cathartic by-product of ritual? The question proposes a binary opposition similar to the duality of basic assumptions and work group, missing their interrelatedness. The outcomes of a group relations conference are a hypothesis, open to ongoing digestion rather than conceived as a dusted and done achievement. Ritual is just an inevitable component, its profitable use depending on the capacity of the staff to interrogate their experience beyond complacency (Lousada, 2015). However, an approach that declines engagement with the notion of the unconscious, confuses means and ends in a reductive aestheticising of what appears an ineffable practice. Borges (1976, p. 12) described the aesthetic experience as "the imminence of a revelation that does not finally occur". It might help to attend to the poetics rather than the aesthetics of group relations, and the substitutions along the paradigmatic axis with their potential for creative (mis)readings, in the awareness of the performative nature of ritual as a transitional space (Winnicott, 1953).

Wittgenstein (1953) posited that there is a difference between following the rules and having an understanding of the rules. A necessary expectation (requisite?) of group relations staff is to have been themselves through the maddening experience of psychoanalytic treatment. This, alas, is not always the case, and practitioners are invited to join staff with insufficient understanding of (and a reconciliation with) their own sexual (both loving and sadistic) impulses. This is a strategic mistake since even experienced teams will be pulled towards disavowing the presence of the unconscious in the frenzy of relatedness. At the level of conference design, this results in an endless search for novelty and innovation, evident in forever changing conference formats, devising new structures that, because they appear exciting, disguise the repetitive barrenness of the terrain to be traversed. However, and in spite of its radical impossibility within a world full of strife and destruction, the practice of group relations fosters the capacity to notice the sources of primitive impulses that are essential to allow, get to know, and accept creative unconscious functioning within the boundaries of the ego. It is a tradition full of contradictions that, like artistic production, draws on ritual practice to foster the capacity to sustain the disorder excitement brings about. Like art practice, it is an opportunity for experimentation in translation rather than a solution that reifies the outcome. As Louise Bourgeois has pointed out

the work of art is limited to an acting out, not an understanding. If it were understood, the need to do the work would not exist anymore. ... Art is a 
guaranty of sanity but not liberation, it comes back again and again. (Bourgeois, 2012, p. 7)

A commitment to truth in spite of the fear and attraction indissolubly linked concerning the violence in the unconscious-the primal scene, the violence of primitive sexuality, the fear of unsatisfied craving, the enjoyment of power in an asymmetric relationship, the death drive-seems a necessary requisite for engagement with and the development of the performance-driven, complex and (in Laplanche's sense) enigmatic practice of working on staff in group relations conferences represented by the horror and pleasure in the text Bourgeois embroidered in an artwork from 1996 (Larratt-Smith, 2012, plate 88):

I have been to hell and back. And let me tell you, it was wonderful.

\section{References}

Apter, M. (2008). Reversal theory, Victor Turner and the experience of ritual. Journal of Consciousness Studies, 15(10-11): 184-203.

Armstrong, D. (2005). The work-group revisited: reflections on the practice and relevance of group relations. In: R. French (Ed.), Organization in the Mind. Psychoanalysis, Group Relations, and Organizational Consultancy (pp. 139-150). London: Karnac.

Armstrong, D. (2012). Terms of engagement: looking backwards and forwards at the Tavistock enterprise. The Eric Miller Memorial Lecture 2012. Organisational \& Social Dynamics, 12(1): 106-121.

Beattie, J. (1966). Ritual and social change. Man, 1(1): 60-74.

Bell, C. (1992). Ritual Theory, Ritual Practice. Oxford: Oxford University Press.

Bell, C. (1997). Ritual-Perspectives and Dimensions. Oxford: Oxford University Press.

Bion, W. R. (1961). Experiences in Groups and Other Papers. London: Tavistock.

Bleger, J. (1967). Psycho-analysis of the psycho-analytic frame. International Journal of Psycho-Analysis, 48: 511-520.

Borges, J. L. (1976). La muralla y los libros. In: Otras Inquisiciones (pp. 9-12). Buenos Aires: Alianza Emecé.

Botella, C., \& Botella, S. (2013). Psychic figurability and unrepresented states. In: H. Levine, G. Reed, \& D. Scarfone (Eds.), Unrepresented States of Mind and the Construction of Meaning. Clinical and Theoretical Contributions (pp. 95-121). London: Karnac.

Bourgeois, L. (2012). Louise Bourgeois-The Return of the Repressed, P. Larratt-Smith (Ed.). London: Violette Editions. 
Britzman, D. (2009). The Very Thought of Education: Psychoanalysis and the Impossible Professions. New York: New York State University.

Dewey, J. (1916). Democracy and Education: An Introduction to the Philosophy of Education. New York: Free Press, 1997.

Douglas, M. (1970). The healing rite. Man, 5(2): 302-308.

Eng, E. (1980). Locke's tabula rasa and Freud's "mystic writing-pad". Journal of the History of Ideas, 41(1): 133-140.

Fletcher, J. (2007). Seduction and the vicissitudes of translation: the work of Jean Laplanche. The Psychoanalytic Quarterly, 76(4): 12411291.

Freud, S. (1905d). Three Essays on the Theory of Sexuality. S.E., 7: 123-243. London: Hogarth.

Freud, S. (1925a). A note upon the "mystic writing-pad". S.E., 19: 225-232. London: Hogarth.

Freud, S. (1941f[1938]). Findings, ideas, problems. S.E., 23: 299-300. London: Hogarth.

Gaster, T. (1966). Thespis: Ritual, Myth and Drama in the Ancient Near East. New York: Harper \& Row.

Geertz, C. (1973). Religion as a cultural system. In: The Interpretation of Cultures (pp. 87-125). New York: Basic Books.

Girard, R. (1979). Violence and the Sacred. Baltimore, MD: Johns Hopkins University Press.

Gosling, R. (1981). A study of very small groups. In: D. Colman \& M. Geller (Eds.), Group Relations Reader 2 (pp. 151-161). Jupiter, FL: A K Rice Institute.

Green, A. (1995). Has sexuality anything to do with psychoanalysis? International Journal of Psychoanalysis, 76(5): 871-883.

Halifax, J. (1982). Shaman: the Wounded Healer. London: Thames \& Hudson.

Hayden, C., \& Molenkamp, R. (2002). Tavistock Primer II. Jupiter, FL A K Rice Institute.

Jaques, E. (1955). Social systems as a defence against persecutory and depressive anxiety. In: M. Klein, P. Heimann, \& R. Money-Kyrle (Eds.), New Directions in Psycho-Analysis (pp. 478-498). London: Karnac, 1985.

Klein, M. (1946). Notes on some schizoid mechanisms. International Journal of Psychoanalysis, 27: 99-110.

Kohon, G. (1999). No Lost Certainties to be Recovered. London: Karnac.

Kohon, G. (2014). Personal communication.

Laplanche, J. (1970). Life and Death in Psychoanalysis. Baltimore, MD: Johns Hopkins University Press, 1985.

Laplanche, J. (1989[1987]). New Foundations for Psychoanalysis. Oxford: Blackwell. 
Laplanche, J. (1999). Transference: its provocation by the analyst. In: J. Fletcher (Ed.), Essays on Otherness (pp. 214-233). London: Routledge.

Laplanche, J. (2002). Les échecs de la traduction. In: Sexual: La sexualité élargie au sens freudien, 2000-2006. Paris: Presses Universitaires de France.

Larratt-Smith, P. (Ed.) (2012). Louise Bourgeois-The Return of the Repressed. London: Violette Editions

Lousada, J. (2015). Keynote paper at "Doing the business of group relations conferences. Un/conscious dynamics, systems and ethics". Belgirate V Conference, 2015 Tavistock Institute, Italy, 5-8 November.

Miller, E. (1990). Experiential learning in Groups II. Recent developments in dissemination and application. In: E. Trist, E \& H. Murray (Eds.), The Social Engagement of Social Science. Volume 1: The Socio-psychological Perspective (pp. 186-198). London: Free Association.

Mitchell, J. (2012). The sublime jealousy of Louise Bourgeois. In: P. Larratt-Smith (Ed.), Louise Bourgeois-The Return of the Repressed (pp. 47-67). London: Violette Editions.

Rustin, M. (2003). Learning about emotions: the Tavistock approach. European Journal of Psychotherapy, Counselling and Health, 6(3): 187-208.

Scarfone, D. (2013). A brief introduction to the work of Jean Laplanche. International Journal of Psychoanalysis, 94(3): 545-566.

Steiner, J. (1985). Turning a blind eye: the cover up for Oedipus. International Review of Psycho-Analysis, 12(2): 161-172.

Triest, J., \& Nutkevitch, A. (2009). "Doth my father yet live". Psychoanalysis and group relations conferences: revisited. In: A. Aram, R. Baxter, \& A. Nutkevitch (Eds.), Adaptation and Innovation: Theory, Design and Role Taking in Group Relations Conferences and Their Applications, Vol. 2 (pp. 51-68). London: Karnac.

Turner, V. (1962). Chihamba, the White Spirit. Rhodes-Livingston Paper 33. Manchester: Manchester University Press.

Turner, V. (1969). Liminality and communitas. In: The Ritual ProcessStructure and Anti-structure (pp. 94-130). New York: Aldine de Gruyter.

Van Gennep, A. (1960). The Rites of Passage. Chicago, IL: University of Chicago Press.

Van Reekum, G., \& Gottlieb, D. (2009). Is group relations a good regulator? Ritualization as a basic assumption mentality. In: E. Aram, R. Baxter, \& A. Nutkevitch (Eds.), Adaptation and Innovation: Theory, Design and Role Taking in Group Relations Conferences and Their Applications, Vol. 2 (pp. 215-231). London: Karnac. 
Whitehead, C. (2001). Social mirrors and shared experiential worlds. Journal of Consciousness Studies, 8(4): 3-36.

Winnicott, D. W. (1953). Transitional objects and transitional phenomena-a study of the first not-me possession. International Journal of Psychoanalysis, 34: 89-98.

Wittgenstein, L. (1953). Philosophical investigations. Chichester: Wiley, 2009.

Zor, R., Keren, H., Hermesh, H., Szechtman, H., Mort, J., \& Eilam, D. (2009). Obsessive-compulsive disorder: a disorder of pessimal (nonfunctional) motor behavior. Acta Psychiatrica Scandinavica, 120(4): 288-298. 